\author{
Bharat Mehra \\ University of Alabama, Tuscaloosa, Alabama, USA.
}

Vandana Singh

University of Tennessee, Knoxville, Tennessee, USA.

Everette Scott Sikes

University of Tennessee, Knoxville, Tennessee, USA.

\title{
A Model of Community-Engaged Scholarship Across "Institutional Borders" to Assess the Role of Rural Libraries in Community Engagement in the Southern and Central Appalachia
}

\begin{abstract}
The paper explores a model of community-engaged scholarship developed in a planning grant entitled "Assessment of Rural Library Professionals' Role in Community Engagement in the Southern and Central Appalachian Region: Mobilization from Change Agents to Community Anchors (CA2CA@SCA-RL)" awarded by the Institute of Museum and Library Services to the University of Tennessee, recently sub-contracted to the University of Alabama (July 2017 - June 2019). It provides insights bridging "institutional borders" at multiple levels to spotlight "invisible voices" of rural librarians and glimpses best practices in community engagement that might be relevant to other rural areas historically facing similarly challenging sociocultural/socio-economic circumstances.
\end{abstract}

Keywords

Model of Community-Engaged Scholarship, Community Engagement, "Institutional Borders", Rural Libraries, Southern and Central Appalachia.

\section{Introduction}

In keeping with the 2019 CAIS-ACSI conference theme of "Information Studies in the World: Conversations Across Institutional Boundaries" this paper briefly presents a model of community-engaged scholarship developed in a planning grant entitled "Assessment of Rural Library Professionals' Role in Community Engagement in the Southern and Central Appalachian Region: Mobilization from Change Agents to Community Anchors (CA2CA@SCA-RL)" awarded by the Institute of Museum and Library Services' (IMLS) Laura Bush $21^{\text {st }}$ Century Librarian-FY 2017 Guidelines (Community Anchors Project Category) to the University of Tennessee (UTK), subcontracted to the University of Alabama (UA) this year (July 2017 - June 2019). (For grant details, see URL: https://scholar.cci.utk.edu/ca2ca-sca-rl/).CA2CA@SCA-RL involved quantitative/qualitative data collection from rural librarians in the Southern and Central Appalachia (SCA) about their perspectives/experiences in community engagement and what past/current role they play in community-centered processes (Mehra, Sikes, and Singh, 2018). The model of community-engaged scholarship was developed through grant conceptualization/implementation in bridging multiple "institutional borders" to address SCA rural digital divides (Mehra, Sikes, and Singh, under review).CA2CA@SCA-RL spotlights unacknowledged "invisible voices" of rural 
librarians and glimpses best practices/outcomes that might be relevant to other rural areas historically facing similarly challenging socio-cultural/socio-economic circumstances.

The U. S. Bureau of the Census defines "rural" as areas with fewer than 2,500 people and open territory (Economic Research Service, 2007). The Encyclopedia of Rural America defines the related concept of "nonmetropolitan" counties to describe housing developments outside the boundaries of metropolitan areas that have no cities with as many as 50,000 residents (Rathge, 1997, p. 627), in addition to being non-urbanized (Office of Management and Budget, 1998). The word "rural" in this paper reflects both meanings.

So far, CA2CA@SCA-RL's community-engaged scholarship has involved collaborations with state, county, and other SCA rural libraries to research their community engagement alliances and facilitated framework development and action plan for them moving forward. The SCA is an ideal location to conduct this work because the Appalachian region has traditionally faced economic, social, and cultural challenges that have adversely affected its residents (Appalachian Regional Commission, 2010; Fritsch and Gallimore, 2007). Select research is now beginning to assess the region's assets, including rural library efforts, and how they are overcoming their past challenges (American Library Association, 2011; ARC, 2015a; Mehra, Bishop, and Partee II, 2017a).CA2CA@SCA-RL is such an example of how the library is and can play a central role in community engagement to bridge rural digital divides and develop sustainable economic viability.

\section{The Context of Need for the CA2CA@SCA-RL}

The Appalachian Regional Commission (ARC) (1974), created as a Unites States federalstate partnership, identifies Central Appalachia to include: West Virginia's nine southernmost counties, eastern Kentucky, Virginia's southwestern tip, and the northwestern portion of Tennessee's Appalachian area (Bush, 2003), while Southern Appalachia includes most of Appalachian Virginia and Tennessee as well as the western Carolinas and the northern parts of Georgia, Alabama, and Mississippi.

The SCA has experienced "double jeopardy" owing to:

- A history of logging, coal-mining, and geographic isolation that generated a psychological dis-connect, perpetuated in a "religiously and politically conservative climate", leading to impoverished conditions, limited availability of resources/technology, illiteracy, amongst other debilitating circumstances (Fisher and Smith, 2012; Ludke and Obermiller, 2012; Mehra, 2017; Mehra, Bishop, and Partee II, 2016a).

- Images during early $20^{\text {th }}$ century of "yellow journalism" and their solely sensationalist coverage of deficit aspects that persisted in public imagination, academic/scholarly discourse, and news coverage until recent times (Cooper and Terrill, 2009; Drake, 2003; Escott, Goldfield, McMillen, and Turner, 1999; Eller 2008).

The SCA is part of the 205,000 square mile area around the Appalachian Mountains where in August 2017, out of its total 420 designated counties, 84 were distressed, 115 were at-risk, and 208 were transitional (ARC, n.d.a). Forty-two percent of Appalachian region residents live in rural areas, compared with 20 percent of the national population (ARC, 2015b) with two-thirds of the Appalachian counties with populations less than 50,000 people, and 125 counties with fewer than 20,000 inhabitants (U.S. Census Bureau, 2012). These rural communities have historically experienced limited financial opportunities, low information literacy, inadequate information technology, amongst other marginalizing circumstances (Mehra and Singh, 2017; Mehra, Singh, Hollenbach, and Partee II, 2017; Spatig et al. 2009). Over 2.5 million people reside in 
rural areas of the Appalachian region (ARC, n.d.b.; Mehra, Singh, and Sikes, 2018). According to the IMLS' Public Library Survey, there were almost half (46.8\%) rural libraries of the total 8,956 public libraries in the United States (Swan, Grimes \& Owens, 2013). This same study found that although per capita revenue had decreased over a three-year period, visitation and circulation had increased for small and rural libraries. CA2CA@SCA explores community engagement in all kinds of SCA rural libraries though public libraries are a significant stakeholder group. This paper spotlights an instance of community-engaged scholarship with rural libraries that are playing a constructive role in their asset management and local capacity building to overcome past socio-environmental limitations (Mehra, Bishop, and Partee II, 2018; Scruggs 2010). It challenges past solely deficit notions and parochial picture of the SCA and rural library environments painted in American society (Cash 1991; Cobb 2007; Wyatt-Brown 2008).

\section{Community-Engaged Scholarship and Information Professionals}

Community-engaged scholarship reflects a recent trend in the $21^{\text {st }}$ century of North American colleges and universities (especially land-grant institutions) proactively applying their academic pursuits towards community building and community development (Harris, 2008; Mehra, Bishop, and Partee II, 2016b; Soska and Butterfield, 2004). The Higher Education Network for Community Engagement (2007) and the Carnegie Community Engagement Classification, amongst others, call for "Collaboration between institutions of higher education and their larger communities (local, regional/state, national, global) for the mutually beneficial exchange of knowledge and resources in a context of partnership and reciprocity" (Campus Compact, 2018). Dwindling economic resources in widespread regions have also brought about a demand for greater accountability of the universities' research-teaching-service activities (Gupton et al., 2014).

CA2CA@ is a unique action research (AR) example of collaborations between library and information science (LIS) researchers and rural librarians, together seeking to improve a situation in focused geographic regions (Greenwood and Levin, 1998).

CA2CA@SCA-RLAR characteristics include community participation at varied levels in research and action, learning in collaboration, community inquiry into everyday experiences, mixed methods use, situated applications, and concrete outcomes (Kemmis and McTaggart, 1988; Mehra, 2006; Rahman, 2008; Stringer, 1999).

\section{CA2CA@SCA-RL Plan}

The following project objectives were achieved to document SCA rural librarians' perspectives/experiences in community engagement:

Objective 1: Two online quantitative surveys provided SCA rural librarians' feedback (from paraprofessionals, staff, managers/directors) of existing ( $\mathrm{n}=126)$ and future $(n=40)$ engagement initiatives regarding their "aboutness", partners, challenges, and outcomes in eleven domains including: agriculture, diversity, economy, education, environment, government, health, information technology, law/justice, manufacturing/industry, and social welfare.

Objective 2: Thirty rural librarians in 15 qualitative interviews and five focus groups (with three librarians each) discussed their role as community anchors to conceptualize a community engagement framework prototype identifying potential actions, resources, and best practices.

Objective 3: The team has drafted deliverables (Community Engagement Framework \& Strategic Action Plan) based on the above feedback and input from an advisory board of 11 rural librarians who also assisted in project planning/design/implementation. 
Other publications will share these details (e.g., Mehra, Sikes, and Singh, forthcoming; etc.). This paper explores the CA2CA@SCA-RL's community-engaged scholarship in bridging multiple "institutional borders" to overcome SCA rural digital divides.CA2CA@SCA-RL is serving as pilot experience and assessment test-bed to expand using similar strategies for rural environments nationwide based on future funding (Mehra, Bishop, and Partee II, 2017b). To train future professionals provide better services, we are integrating grant experiences into the LIS classroom/curriculum, sharing at regional/national conferences, and publishing in professional journals. Expected outcomes will provide generalizable data on how rural libraries empower/engage communities, develop/test deliverables from systematic collection of rural datasets, and expand research of rural library community engagement.

\section{Bridging "Institutional Borders"}

This paper represents meanings emerging from media culture and cultural studies' symbolic multimodality perspective of "borderlands" (in the plural) conceived as "complex, constructed, impure hybrids, with crucial overlaps" that are contextualized, dialogic, and assume critical interpretations in the CA2CA@SCA-RL and its rural settings (Fornas, 2002, p. 89). It resonates with metaphorical borderland research of its assessment of pedagogies, epistemologies, and educational practices as "symbolic barriers that divide communities along race, class, gender, and sexual orientation lines, academic disciplines, and organizational structures" (Elenes, 2006). The paper's use of "institutional" also relates to a symbolic recognition of structure (as in social movements) in its demarcation of knowledge/phenomenon topics into distinct areas of scrutiny (Goodwin, 2003). The paper highlights the bridging of CA2CA@SCA-RL's "institutional borders" according to multiple levels of functional categorizations represented in Table 1.

\begin{tabular}{|c|c|c|c|}
\hline Sr. No. & Element & Description & Application in CA2CA@SCA-RL \\
\hline 1. & Approach & The strategy. & $\begin{array}{l}\text { CA2CA@SCA-RL's community- } \\
\text { engaged scholarship. }\end{array}$ \\
\hline 2. & Who & $\begin{array}{l}\text { Stakeholders } \\
\text { involved as initiators } \\
\text { and subjects of } \\
\text { scrutiny. }\end{array}$ & $\begin{array}{l}\text { LIS researchers engaging in } \\
\text { scholarship with rural librarians } \\
\text { about their external stakeholder } \\
\text { collaborations. }\end{array}$ \\
\hline 3. & What & Object of scrutiny. & $\begin{array}{l}\text { Community engagement in eleven } \\
\text { domains and their "aboutness", } \\
\text { partners, challenges, and outcomes. }\end{array}$ \\
\hline 4. & Why & $\begin{array}{l}\text { Underlying } \\
\text { motivations shaping } \\
\text { community-engaged } \\
\text { scholarship. }\end{array}$ & $\begin{array}{l}\text { Assessment of SCA rural } \\
\text { librarians' role in community } \\
\text { engagement } \\
\text { (unacknowledged/“invisible”). }\end{array}$ \\
\hline 5. & Where & $\begin{array}{l}\text { Area of stakeholder } \\
\text { involvement; } \\
\text { implementation of } \\
\text { community-engaged } \\
\text { scholarship. }\end{array}$ & $\begin{array}{l}\text { - Administration across two } \\
\text { institutions (UTK and UA). } \\
\text { - Feedback from rural librarians in } \\
\text { ten SCA states. }\end{array}$ \\
\hline 6. & How & $\begin{array}{l}\text { Methods used in } \\
\text { community-engaged } \\
\text { scholarship. }\end{array}$ & $\begin{array}{l}\text { - Two online surveys. } \\
\text { - Interviews/focus groups. } \\
\text { - Summit discussions. } \\
\text { - GIS and website representations. }\end{array}$ \\
\hline 7. & Deliverables & $\begin{array}{l}\text { Identifies the } \\
\text { emerging }\end{array}$ & $\begin{array}{l}\text { - Community-engaged } \\
\text { framework and strategic action }\end{array}$ \\
\hline
\end{tabular}




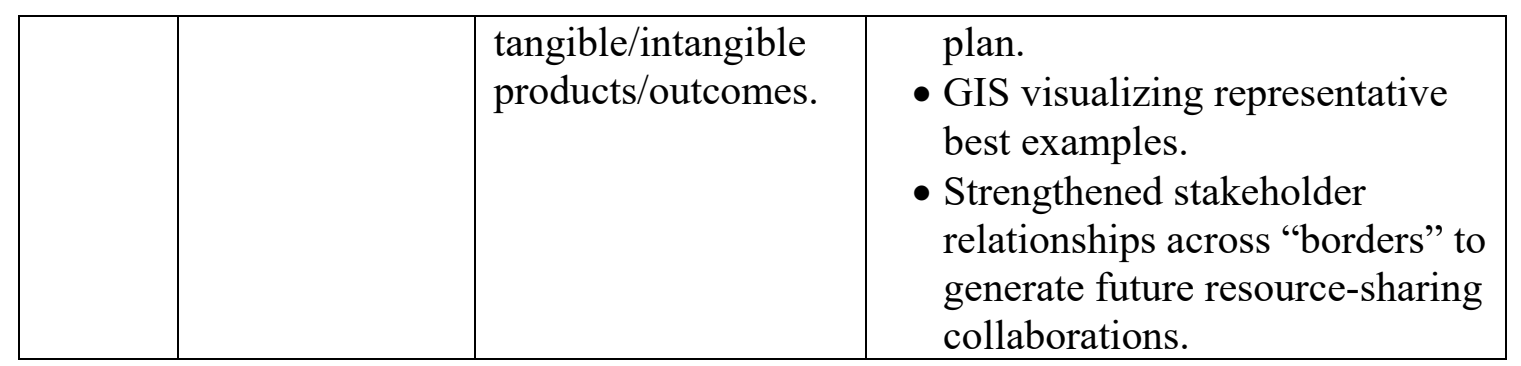

Table 1: CA2CA@SCA-RL's model of community-engaged scholarship bridging multiple "institutional borders."

\section{Conclusion}

Though the paper focus is not on detailed analysis of best practices emerging in the CA2CA@SCA-RL, the following glimpse provides possible application in other rural settings:

- Adopting the aboutness-collaborators-challenges-outcomes strategy to document community engagement is practical/useful in describing rural library efforts.

- Conducting an inventory of engagement alliances in the eleven domains paints an extended picture of rural libraries' impact across "institutional borders."

- Applying multiple research methods (including GIS) tells holistic story of rural library experiences.

- Engaging rural libraries and others across boundaries (e.g., SCA states) strategically strengthens alliances and future resource-sharing.

CA2CA@SCA-RL's next step involves organizing a summit in Tennessee and possibly another in Alabama to discuss operationalizing grant deliverables (e.g., framework, strategic action plan) with key stakeholders. The CA2CA@SCA-RL's model of community-engaged scholarship allowed us to bridge multiple "institutional borders" to overcome SCA's rural digital divides and highlight rural libraries' positive efforts. The model elements of approach-who-what-why-where-how-deliverables in the CA2CA@SCA-RL addressed an urgent concern in providing visibility to SCA rural librarians' work that has been overlooked/marginalized in past efforts (to get replicated in future studies). Applying AR led to development of tangible information-related products through local collaborations with key partners who benefited in the region. This paper urges information science professionals to get involved in community-engaged scholarship with their rural stakeholders and further their impact in community development. The study offers possibilities of extending best practices to other rural areas beyond the SCA region.

\section{Acknowledgments}

The authors appreciate the IMLS grant reported in this paper. We also acknowledge contributions of research respondents and CA2CA@SCA-RL partners including: 1) Blount County Public Library, TN (http://www.blountlibrary.org/); 2) Clinch River Regional Library, TN (http://sos.tn.gov/products/tsla/clinch-river-regional-library); 3) Library of Virginia, VI (http://www.lva.virginia.gov/); 4) Sevier County Public Library System, TN (https://www.facebook.com/SevierCountyPublicLibrarySystem/); 5) Wiggins Memorial Library, NC (https://lib.campbell.edu/).

\section{Reference List}

American Library Association. (2011). The State of America's Libraries: A Report from the American Library Association. Special Issue, American Libraries: The Magazine of the American Library Association. Chicago, IL: ALA. Retrieved 
January 25, 2019, from https://americanlibrariesmagazine.org/wpcontent/uploads/2011/04/State_of_Americas_Libraries_2011.pdf.

Appalachian Regional Commission (ARC). (2015a). Investing in Appalachia's Future:

The Appalachian Regional Commission's Five-Year Strategic Plan for Capitalizing on Appalachia's Opportunities 2016-2020. ARC, Washington, DC. Retrieved January 15, 2019, from

https:/www.arc.gov/images/newsroom/publications/sp/InvestinginAppalachiasFutu reARCs2016-2020StrategicPlan.pdf.

Appalachian Regional Commission. (ARC). (February 2015b). Appalachia Then and Now: Examining Changes to the Appalachian Region Since 1965. Washington, DC: ARC. Retrieved January 25, 2019, from https://www.arc.gov/assets/research_reports/AppalachiaThenAndNowCompiledRe ports.pdf.

Appalachian Regional Commission. (ARC) (2010). Moving Appalachia forward: Appalachian Regional Commission strategic plan 2011-2016. Washington, DC: Appalachian Regional Commission. Retrieved July 20, 2018, from http://www.arc.gov/images/ newsroom/publications/sp/ARCStrategicPlan20112016.pdf.

Appalachian Regional Commission. (ARC) (1974). The new Appalachian subregions and their development strategies. Appalachia, a Journal of the Appalachian Regional Commission 8: 11-27.

Appalachian Regional Commission. (n.d.a). County Economic Status in Appalachia, FY 2018. Retrieved October 5, 2017, from https://www.arc.gov/research/MapsofAppalachia.asp?MAP_ID=137.

Appalachian Regional Commission (n.d.b.). The Appalachian Region. Washington, DC: Appalachian Regional Commission. Retrieved October 23, 2017, from https://www.arc.gov/appalachian_region/TheAppalachianRegion.asp.

Bush, W. S. 2003. Bridging the gap between culture and mathematics: The Appalachian perspective. Athens, GA: Appalachian Collaborative Center for Learning, Assessment, and Instruction in Mathematics, Ohio State University.

Campus Compact. (2018). Carnegie Community Engagement Classification. Retrieved January 25, 2019, from https://compact.org/initiatives/carnegie-communityengagement-classification/.

Cash, W. J. (1991). The mind of the South. New York, NY: Vintage Books.

Cobb, J. C. (2007). Away down south: A history of Southern identity. Oxford, UK: Oxford University Press.

Cooper, W. J. Jr., and Terrill, T. E. (2009). The American South: A history (4th ed., Vol. 2). Lanham, MD: Rowman and Littlefield Publishers.

Drake, R. B. (2003). A History of Appalachia (Reprint ed.). Lexington, Kentucky: University of Kentucky

Economic Research Service. 2007. Measuring rurality: What is rural? Washington, DC: Economic Research Service, The Economics of Food, Farming, Natural Resources, and Rural America, U.S. Department of Agriculture. Retrieved December 20, 2018, from http://www.ers.usda.gov/Briefing/Rurality/WhatIsRural/.

Elenes, C. A. (2006). Borderlands, Pedagogies, and Epistemologies. In D. D. Bernal, C. A. Elenes, F. E. Godinez, and S. Villenas (eds.), Chicana/Latina Education in Everyday Life: Feminista Perspectives on Pedagogy and Epistemology (pp. 215218). New York: State University of New York Press.

Eller, R. D. (2008). Uneven ground: Appalachia since 1945. Lexington, KY: The University Press of Kentucky. 
Escott, P. D., Goldfield, D. R., McMillen, S. G., and Turner, E. H. (1999). Major problems in the history of the American South: Documents and essays, Volume II: The New South ( $2^{\text {nd }}$ ed.). Boston, MA: Houghton Mifflin Harcourt.

Fisher, S. L. and Smith, B. E. (Eds.). 2012. Transforming places: Lessons from Appalachia ( $1^{\text {st }}$ ed.). Cha, mpaign, IL: University of Illinois Press.

Fornas, J. (2002). Passages Across Thresholds: Into the Borderlands of Meditation. Convergence: The International Journal of Research into New Media Technologies, 8(4), 89-106.

Fritsch, A., and Gallimore, P. (2007). Healing Appalachia: Sustainable living through appropriate technology. Lexington, KY: The University Press of Kentucky.

Goodwin, J. (2003). Rethinking Social Movements: Structure, Meaning, and Emotion: People, Passions and Power (People, Passions, and Power: Social Movements, Interest Organizations, and the Political Process). New York: Rowman \& Littlefield Publishers, Inc.

Greenwood, D. J., and Levin, M. (1998). Introduction to Action Research: Social Research for Social Change. Thousand Oaks, CA: SAGE Publications, Incorporated.

Gupton, J. T., Sullivan, A. L., and Johnston-Goodstar, K. (2014). The Role of University Engagement in the Community. International Journal of Educational Reform, 23(3), 181-190.

Harris. B. R. (2008). Communities as Necessity in Information Literacy Development: Challenging the Standards. The Journal of Academic Librarianship 34 (3): 248-255.

Higher Education Network for Community Engagement. (2007). HENCE. Retrieved November 2, 2018, from http://henceonline.org/.

Kemmis, S. and McTaggart, R. (1998). The Action Research Planner. Victoria: Deakin University Press.

Ludke, R. L., and Obermiller, P. J. (Eds.). 2012. Appalachian health and well-being (1st ed.), Lexington, KY: The University Press of Kentucky.

Mehra, B. (2017). Mobilization of Rural Libraries towards Political and Economic Change in the Aftermath of the 2016 Presidential Election. The Library Quarterly: Information, Community, Policy (Special Issue: Aftermath: Libraries, Democracy, and the 2016 Presidential Election), 87(4), 369-390.

Mehra, B. (2006). An Action Research (AR) Manifesto for Cyberculture Power to "Marginalized" Cultures of Difference. In: D. Silver and A. Massanari (eds.), Critical Cyber-Culture Studies (pp. 205-215). New York: New York University Press.

Mehra, B., Bishop, B. W., and Partee II, R. P. (2018). A Case Methodology of Action Research to Promote Economic Development: Implications for LIS Education. Journal of Education for Library and Information Science, 59(1-2), 48-65.

Mehra, B., Bishop, B. W., and Partee II, R. P. (2017a). How Do Public Libraries Assist Small Businesses in Rural Communities? An Exploratory Qualitative Study in Tennessee. Libri International Journal of Libraries and Information Studies, 67(4), 245-260.

Mehra, B., Bishop, B. W., and Partee II, R. P. (2017b). Small Business Perspectives on the Role of Rural Libraries in Economic Development. The Library Quarterly: Information, Community, Policy, 87(1), 17-35.

Mehra, B., Bishop, B. W., and Partee II, R. P. (2016a). Information Science Professionals as Community Action Researchers to Further the Role of Rural Public Libraries in Small Business Economic Development: A Case Study of Tennessee. Canadian Journal of Information and Library Science, 40(4), December 2016, 289-299.

Mehra, B., Bishop, B. W., and Partee II, R. P. (2016b). Community Partnerships to Further the Role of Rural Public Libraries in Small Business Economic 
Development: A Case Study of Tennessee (Poster Paper). In Xia Lin and Michael Khoo (editors), Proceedings of the iConference 2016: Partnership With Society, Philadelphia, PA, March 20-23, 2016. URL:

https://www.ideals.illinois.edu/bitstream/handle/2142/89386/Mehra465.pdf?sequen $\mathrm{ce}=1$.

Mehra, B., Sikes, E. S., and Singh, V. (2018). Information Technology Use Behaviors of Community-Engaged Rural Librarians: A Future beyond the Theory-Practice Discourse to Integrate Impact (short paper), 2018 ASIS\&T SIG-USE Symposium:

Moving Toward the Future of Information Behavior Research and Practice, Vancouver, Canada, November 10, 2018.

Mehra, B., Sikes, E. S., and Singh, V. (forthcoming). Scenarios of Health Engagement Experiences and Health Justice in Rural Libraries. International Journal of Information, Diversity, \& Inclusion (Special Issue: Health Justice. Edited by Beth St. Jean, Gagan Jindal, and Yuting Liao).

Mehra, B., Sikes, E. S., and Singh, V. (under review). Scenarios of Technology Use to Promote Community Engagement: Overcoming Marginalization and Bridging Digital Divides in the Southern and Central Appalachian Rural Libraries. Information Processing \& Management (Special Issue: Marginalized Communities, Emerging Technologies, and Social Innovation in the Digital Age. Edited by Jia Tina Du, Iris Xie, and Jenny Waycott).

Mehra, B., and Singh, V. (2017). Library Leadership-In-Training as Embedded Change Agents to Further Social Justice in Rural Communities: Teaching of Library Management Subjects in the ITRL and ITRL2. In Nicole A. Cooke and Miriam E. Sweeney (Eds.), Teaching for Justice: Implementing Social Justice in the LIS Classroom. Sacramento, CA: Library Juice Press.

Mehra, B., Singh, V., Hollenbach, N., and Partee II, R. P. (November 2017). Rural Librarians as Change Agents in the $21^{\text {st }}$ Century: Applying Community Informatics in the Southern and Central Appalachian Region to Further ICT Literacy Training. In Brian Real (ed.), Rural and Small Public Libraries: Challenges and Opportunities (Advances in Librarianship Series). Bingley, United Kingdom: Emerald Group Publishing.

Mehra, B., Singh, V., Sikes, E. S. (2018). Assessment of Rural Library Professionals' Role in Community Engagement in the Southern and Central Appalachian Region: Mobilization from Change Agents to Community Anchors (CA2CA@SCA-RL) (Works-In-Progress Poster). Association for Library and Information Science Education (ALISE) Annual Conference: The Expanding LIS Education Universe, Denver, Colorado, February 6-9, 2018.

Office of Management and Budget. (1998, December 21). Part III alternative approaches to defining metropolitan and nonmetropolitan areas. Federal Register. 63 (637052670561). Retrieved January 20, 2019, from http://www.whitehouse.gov/omb/inforeg/msa.pdf.

Rathge, R. W. (1997). Rural demography. In Encyclopedia of rural America: The land and the people (pp. 626_629). Santa Barbara, CA: ABCCLIO.

Rahman, M. A. (2008). Some Trends in Participatory Action Research. In Peter Reason and Hilary Bradbury (eds.), The SAGE Handbook of Action Research (pp. 49-62). Thousand Oaks, CA: SAGE Publications, Incorporated.

Scruggs, C. E. (2010). The View from Brindley Mountain: A Memoir of the Rural South. North Charleston, SC: BookSurge Publishing.

Soska, T., and Butterfield, A. K. J. (2004). University-Community Partnerships: Universities in Civic Engagement. Binghamton, NY: Haworth Social Work Practice Press. 
Spatig, L., Gaines, S., MacDowell, R., Sias, B., Olson,L., and Adkins, C. (2009). "Like a Mountain: Performing Collaborative Research with Youth in Rural Appalachia."

Collaborative Anthropology 2:177-212.

Stringer, E. (1999). Action Research. Thousand Oaks, CA: Sage.

Swan, D. W., Grimes, J., Owens, T., Vese Jr, R. D., Miller, K., Arroyo, J., ... \& O’Shea, P. (2013). Public libraries in the United States survey: Fiscal year 2010.

Washington, DC: Institute of Museum and Library Services, January. Retrieved November 10, 2018, from http://www.

imls.gov/research/public_libraries_in_the_us_fy_2010_report. aspx.

U.S. Census Bureau. (December 6, 2012). 2007-2011 American Community Survey. Census Bureau Releases American Community Survey Estimates, Most Detailed Portrait of Every U.S. Community (Newsroom Archive: Press Release). Retrieved October 23, 2017, from

https://www.census.gov/newsroom/releases/archives/american_community_survey_a $\mathrm{cs} / \mathrm{cb} 12-228 . \mathrm{html}$.

Wyatt-Brown, B. (2008). Southern honor: Ethics and behavior in the Old South. History E-Book Project Reprint Series. New York, NY: ACLS Humanities E-Book. 